\title{
Alegrias e desventuras do paladar: a alimentação no Brasil holandês
}

\author{
Bliss and misfortunes of taste: food \\ from the Brazilian Dutch Colony
}

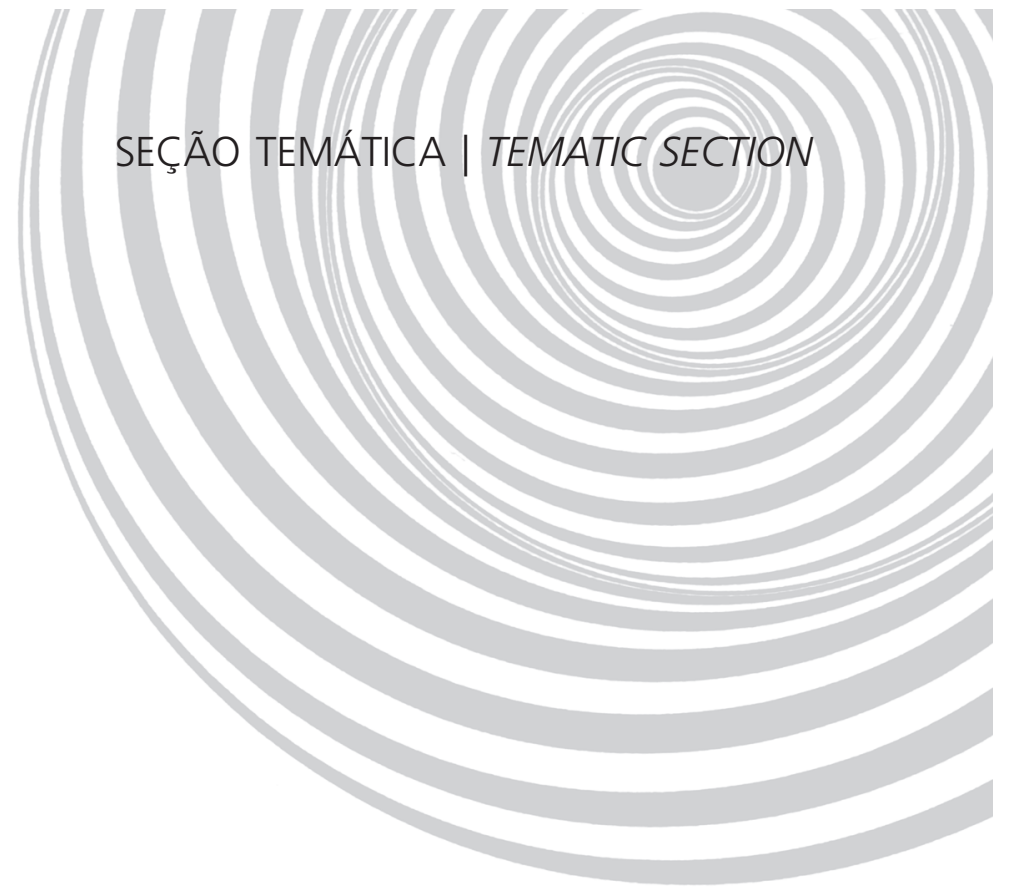

Claude Guy PAPAVERO'

\section{R E S U M O}

O objetivo deste trabalho é desenvolver uma descrição histórica dos eventos relacionados à problemática do abastecimento alimentar durante a conquista de parte do Nordeste brasileiro, entre 1630 e 1654, pela Companhia das Índias Ocidentais holandesa, que revelou o modo de pensar dos conquistadores e permitiu demonstrar as dificuldades de subsistência no Brasil holandês e a precariedade do domínio político estabelecido. Durante o governo do conde Maurício de Nassau-Siegen, entretanto, os forasteiros maravilhados descobriram o sabor da fauna e da flora local que os colonos portugueses costumavam comer, e adotaram sem demora essas iguarias que eles utilizaram para elaborar imagens convincentes do poder conquistado. A descrição dos hábitos alimentares e dos problemas de abastecimento encontrados na documentação analisada permitiu apontar os parâmetros sócio-culturais que regiam aquela sociedade, favorecendo um enfoque bem documentado sobre a alimentação da época.

Termos de indexação: Alimentação colonial. Antropologia da alimentação. História da alimentação. Brasil Holandês.

A B S T R A C T

An analysis of food resources of the civil population and the occupation army that the Dutch West Indies Company brought to the Northeast of Brazil from 1630 to 1654 demonstrated the hard situation of subsistence of the Brazilian colony and the precariousness of the political dominion established. Under the governorship of count Moritz van Nassau-Siegen, however, the Dutch, enchanted with the flavors of the local fauna and flora that Portuguese colonists were used to eating, soon adopted such delicacies at their tables and used them to develop convincing images of their political power over the land. The description of the food habits and the problems of sully found in the analyzed documents allowed the determination of the sociocultural parameters that governed that society, favoring a well documented focus on the eating habits of that time.

Indexing terms: Colonial alimentary diet. Alimentary anthropology. History of food. Dutch Brazil.

\section{N T R O D U Ç Ã O}

O objetivo deste trabalho é desenvolver uma descrição histórica dos eventos relacionados à problemática da abastecimento alimentar no período do Brasil colonial (segunda metade do século XVII), durante a conquista de parte do Nordeste brasileiro pela Companhia das Índias Ocidentais

\footnotetext{
${ }^{1}$ Doutora em Antropologia. R. Clodomiro Amazonas, 1220, ap. 71, Vl. Olímpia, 04537-002, São Paulo, SP, Brasil. E-mail: <papavero@usp.br>.
} 
holandesa (West Indische Compagny - WIC). Por intermédio das atividades de subsistência, o modo de pensar, de agir e de sentir dos forasteiros desembarcados pôde ser delineado indiretamente, bem como os percalços de seu ajustamento ao estilo de vida brasileiro instituído pelos colonos lusos.

As narrativas sobre o tema indicavam a existência de um hiato curioso entre afirmações mirabolantes de prosperidade colonial e menções recorrentes às dificuldades práticas do abastecimento alimentar. Comparando textos de diversos autores do período, foi possível rastrear o elenco dos problemas cotidianos que afligiam os holandeses. Circunstâncias materiais e valores ideais, conjugados, ilustravam aspectos relevantes da sociedade neerlandesa em vias de se constituir.

\section{As circunstâncias prévias da conquista}

Antes de analisar os contornos do episódio histórico, todavia, seria necessário relembrar alguns de seus aspectos notórios. Apesar do caráter inegavelmente político, o projeto de conquistar a área do Brasil, onde o açúcar era fabricado, desembarcando ali um exército de ocupação e uma população civil composta de voluntários de diversas nacionalidades, foi o empreendimento de uma companhia comercial financiada por acionistas seduzidos pelos lucros proporcionados pela WIC. O motivo principal da guerra residia no empenho das Províncias Unidas dos Países Baixos em se livrar da antiga submissão ao rei da Espanha (que, na época, também reinava em Portugal). Prevendo assaltos ao território holandês, era preferível antecipar a luta e deslocá-la para o ultramar, impedindo a monarquia espanhola de transformar em recursos bélicos as riquezas em ouro, prata e açúcar que recebia das colônias americanas.

A ideia do estabelecimento de uma base sul-americana, para facilitar a perseguição às frotas carregadas de ouro do Caribe e de prata peruana e privar a Espanha dos rendimentos do açúcar brasileiro resultou, portanto, em um ataque a Salvador em 1624, na manutenção dessa primeira capital da colônia em mãos holandesas até meados de 1625 e na conquista de várias capitanias situadas ao norte da Bahia, após a queda de Olinda em 1630. Porém, na prática, nem em Salvador, nem em Olinda, as populações lusas estabelecidas na área rural se submeteram de bom grado, não obstante a perda dos portos por onde escoavam o pau-brasil, o açúcar, o tabaco, o algodão e os couros, e foi preciso dominá-los à força após alguns anos de resistência armada.

\section{Dissabores da alimentação holandesa no Brasil}

Ao desembarcarem, as tropas da WIC encontraram uma grande quantidade de alimentos nas casas de Salvador e de Olinda, abandonadas pelos proprietários. O militar inglês Cuthbert Pudsey relatou a benvinda abundância que celebrou a tomada de Olinda:

E não havia provisões que um soldado não tivesse: vinho, azeite, farinha, uvas, azeitonas e similares, e esses víveres vieram a calhar, tendo todo nosso sustento vindo da Holanda' ${ }^{1}$ (p. 10).

Tamanha fartura, todavia, se esgotou rapidamente. Durante os 12 meses de permanência holandesa em Salvador, um dos grandes problemas causados pelo cerco luso foi a carência dos alimentos frescos. Saques a engenhos do Recôncavo baiano, convites de colonos pretensamente dispostos a confraternizar, emboscadas e tentativas mal sucedidas de negociações para a compra de gado bovino, relatados por Frei Vicente do Salvador ${ }^{2}$, demonstraram a precariedade do domínio territorial alcançado.

Em Recife, entre 1630 e 1632, o exército encurralado em território urbano consumiu quase que exclusivamente gêneros europeus salgados, secos e defumados providos pelas naus batavas. Duarte Coelho de Albuquerque, donatário da capitania de Pernambuco, assinalava orgulhosamente as privações que a resistência lusa infligia aos adversários: 
Unidos assim puderam fazer retirar o gado para o centro e subtraí-lo à cobiça do inimigo, que, estando na posse do Recife havia quase dois anos, ainda não lhe era possível (nem lho consentia o nosso general, já por si, já por seus capitães) comer uma só vaca. Alimentavam-se somente com os gêneros que a Holanda Ihes enviava; pelo que pode dizer-se sem escrúpulos que, estando eles em terra havia tanto tempo, ainda navegavam, pois que não tinham outros mantimentos mais que salgados 3 (p.113).

Durante os dois primeiros anos do Brasil holandês, frutas frescas e carnes verdes foram almejadas em vão, no âmbito de uma guerra cujos procedimentos incluíam o abate de rebanhos bovinos e a destruição de roças de mandioca para impedir o abastecimento alimentar inimigo. Nas colinas de Olinda e nos caminhos entre essa vila e o Recife, os pomares existentes testemunharam emboscadas sangrentas'.

Fome e sede atormentaram os militares da WIC até a adesão ao partido neerlandês do mestiço Calabar, versado nos usos bélicos da terra, além das propostas de aliança contra os portugueses, formuladas por muitos grupos indígenas, quando os forasteiros começaram a vencer bataIhas. A Companhia, auxiliada por indígenas, mamelucos e mulatos, que conheciam bem o território e imaginaram encontrar melhores condições de vida junto aos holandeses, expandiu então seu domínio na área rural. Como ressaltou Evaldo Cabral de Mello, expedições seguiam a bordo de naus até localidades previamente escolhidas. $\mathrm{Na}$ chegada ao destino sigiloso, as tropas desembarcavam e atacavam povoados que nenhum reforço de combatentes lusos defendia ${ }^{4}$. SemeIhantes ataques atemorizavam os colonos, e o saque dos vencidos fornecia gêneros alimentícios frescos. À conquista da Paraíba completada dessa forma, João de Laet observou como o coronel Artichau Arcizewski, passou a substituir os saques por apropriações legais. Distribuiu passaportes aos colonos portugueses em troca de mantimentos e de um juramento de fidelidade à WIC:

[...] o qual estivera ocupado por alguns dias em estabelecer a boa ordem na gente do campo e fazer com que trouxessem ao acampamento as contribuições de víveres (porque acharam que por esse meio obtinham mais carne e farinha de mandioca do que necessário e por tal preço que a manutenção de cada soldado não custava mais de um florim por semana à Companhia) e pôs-se logo a deliberar o que deviam empreender mais contra o inimigo ${ }^{5}$

Por volta de 1636, os holandeses controlavam a maior parte da capitania de Pernambuco e as capitanias de Itamaracá, da Paraíba e do Rio Grande, mas desejavam estender ainda mais seu domínio e necessitavam de fontes locais de subsistência para suplementar o aprovisionamento recebido da metrópole. Alimentar e pacificar o exército de ocupação, a população civil e os colonos lusos remanescentes, em uma região arrasada pela guerra e afetada pela fuga de muitos lavradores portugueses, constituía uma tarefa nevrálgica da qual dependia a manutenção da posse colonial. De modo que a WIC escolheu então o conde Johan Maurits de Nassau-Siegen, humanista e chefe militar reputado, para administrar o território conquistado.

Inúmeros escritos do período mencionaram a irregularidade do abastecimento e as dificuldades da subsistência no Brasil holandês. Os relatórios de Nassau e de seus subordinados, e os comentários espontâneos dos letrados, registraram, ambos, um farto manancial de informações sobre a escassez dos gêneros comestíveis e sobre as medidas paliativas ideadas para fazer frente a situações de carência. O potencial elucidativo das medidas de provimento alimentar não escapou a Antônio Gonsalves de Mello 6 . Em sua obra Tempo dos flamengos, o estudioso apontou o caráter promissor da análise das crises enfrentadas e das soluções instauradas em prol da manutenção da colonização holandesa. 
Porém, as providências oficiais para o sustento da colônia que, por vezes, tiveram o condão de desagradar ao mesmo tempo aos colonos lusos, aos soldados e à maior parte da população civil, não representaram a única fonte de conhecimento revelada pela análise dos procedimentos alimentares batavos. À consideração das formas de ajuste pragmático da dieta às circunstâncias ambientais e sociais do território, seria necessário acrescentar o estudo corolário da maneira como os novos donos do Brasil conceberam uma alimentação condizente com suas pessoas e sua posição social. Com efeito, o fenômeno interessante da transformação de avaliações de gêneros comestíveis palatáveis ou repudiados em classificações simbólicas referentes aos próprios integrantes da nova sociedade, também se tornou evidente nos comentários daqueles que experimentaram delícias e agruras do paladar durante o Brasil holandês.

Apesar da fugaz duração do domínio político alcançado na terra pela Companhia das Índias, os textos dos cronistas e as representações pictóricas dos artistas do conde de Nassau ilustraram temas efetivamente discutidos no Brasil holandês. Os recursos alimentares mais saborosos, frequentes na mesa palaciana, serviram para que, sob a égide de Nassau, se elaborasse uma imagem política convincente do poder holandês. Em contrapartida, a sobrevivência da população mais pobre resultou na ingestão de ingredientes pouco apetecidos.

Entre janeiro de 1637 e meados de 1644, durante os cerca de oito anos de seu governo, o conde de Nassau se empenhou em conciliar os interesses conflitantes dos diversos segmentos de população. Multiplicaram-se os esforços para ampliar o domínio territorial, restaurar a prosperidade abalada pela guerra e dar feições batavas ao Brasil. As práticas eficazes dos colonos portugueses, referentes à produção e ao consumo de alimentos, permaneceram em uso. A farinha de mandioca seca (dita farinha de guerra), a carne bovina seca ou salgada dos rebanhos criados no sertão, a carne fresca de reses conduzidas até o litoral e os barris de peixes apanhados no mar, nas lagoas ou nos rios e conservados secos ou salgados, continuaram a prover reservas estratégicas de alimentos.

Os holandeses aderiram, por conseguinte, à distinção dos colonos lusos, entre os víveres frescos de produção ocasional, que complementavam agradavelmente as refeições, e aos mantimentos básicos, substanciais, resistentes à degradação e facilmente armazenados, que permitiam certo planejamento e controle da produção ${ }^{7}$. Os feijões, que em épocas posteriores de colonização lusa se tornariam ingredientes primordiais da dieta alimentar brasileira, apesar de conhecidos e consumidos pelos índios, pelos portugueses e pelos holandeses, não integravam então o rol dos alimentos indispensáveis.

No cotidiano, a dieta mínima que os mantimentos garantiam era incrementada, segundo a disponibilidade ambiental e o poder aquisitivo de cada indivíduo, por um elenco variado de carnes de criações domésticas ou de caça, de peixes, de moluscos e de crustáceos, de hortaliças ou de legumes europeus, asiáticos, africanos ou nativos, e de preparos que incorporavam açúcar ou subprodutos do açúcar. De forma que, apesar de contar com gêneros comestíveis brasileiros nos armazéns, e de assegurar a obtenção de quantidades imprescindíveis de farinha de mandioca, por meio de decretos considerados abusivos pelos lavradores, a Companhia das Índias nunca deixou de enviar periodicamente para o Brasil naus carregadas de militares, de colonos e de mantimentos europeus. Semelhantes remessas visavam a fortalecer a colônia. Destinavam-se ao sustento de novas expedições bélicas e à obtenção de dinheiro líquido.

Com efeito, na colônia nassoviana, como sob o domínio luso, a população apreciava comer gêneros europeus. As autoridades coloniais batavas (como as antecessoras lusas) continuaram a satisfazer o gosto dos homens abastados e seu desejo de ostentação, vendendo-lhes, por altos preços, gêneros que o Brasil não produzia, como a farinha de trigo, os vinhos ou o azeite. Na volta à metrópole, as frotas neerlandesas carregavam mercadorias produzidas na colônia e, enquanto durou a guerra, o botim apresado pelos corsários. 
Uma vez efetivada a conquista, os acionistas da WIC, acreditando que as fontes locais de abastecimento seriam suficientes, deixaram de enviar aprovisionamento em quantidades adequadas. Em tais circunstâncias, a falta, tanto de numerário quanto de provisões para remunerar e alimentar condignamente a população pesou, e foi necessário abusar de expedientes desagradáveis e desrespeitar as promessas de convívio pacífico feitas aos súditos portugueses, como ressaltou José Hygino Duarte Pereira em seu ensaio sobre a Batalha naval de 1640 e outras peripécias da guerra holandesa no Brasil:

Queixam-se os moradores de que nós lhes tomamos tudo o que elles têm para alimentar a vida e que, sustentando há tanto tempo com o seu os nossos soldados em toda terra, ficaram pobres e cahiram na penúria de víveres; e, entretanto nós não Ihes deixamos tirar do que é nosso, e, pelo contrário, Ihes fechamos tão rigorosamente o Recife que mal podem obter, ainda mesmo para os doentes, um vaso de azeite, uma libra de peixe secco e cousas semelhantes; que desarrazoado é que thes tomemos os generos com que elles se alimentariam, e nada Ihes queiramos dar do que é nosso ${ }^{8}$.

No primeiro relatório endereçado à WIC, em janeiro de 1638, um documento intitulado Breve Discurso sobre o estado das quatro Capitanias conquistadas no Brasil, pelos holandeses, Maurício de Nassau e dois Altos e Secretos Conselheiros relatavam:

Já anteriormente comunicamos que pusemos todos os empregados da Companhia, desde os mais baixos até o mais elevado, às suas próprias expensas no que se refere à alimentação, com que eles se arranjam, e até os soldados, que à velha ração preferem receber o seu soldo e pensão, pois fica-lhes cômodo proverem-se no mercado dos frutos indígenas, sendo que todos os dias se corta carne fresca; não podem porém comprar com o seu soldo muitos víveres da Holanda, a não ser favas, ervilhas, cevada, e preferem as favas e os frutos da terra9 (p.109).

Mesmo em períodos de fartura, a alimentação das tropas se ressentia de economias praticadas às suas custas. O jovem Zacharias Wagener, por exemplo, inicialmente contratado como soldado raso, mas que chegou a ser nomeado despenseiro de Nassau testemunhou, em suas memórias, o preparo culinário de um vegetal brasileiro, o perrexil do mar que crescia em estado selvagem em torno dos fortins e dos cemitérios litorâneos:

Cresce esta erva por toda parte nas terras baixas e salgadas, motivo pelo qual ela mesmo é salgada. Porém, quando a fazemos cozinhar durante bom tempo em água doce, deve-se jogar a água quente fora para cozinhá-la de novo em água doce e assim três ou quatro vezes, perdendo, desta forma, seu mau gosto de sal, dando um bom petisco depois de bem temperada com azeite de oliva e vinagre. Á falta de pão e de outro alimento, durante um ano inteiro fui obrigado, mais do que desejava, a comê-la diariamente, sem manteiga nem azeite ${ }^{10}$.

As expedições bélicas esgotavam os armazéns e resultavam em carências de alimentos acompanhadas de fortes altas dos preços. Nos meses subsequentes, a penúria se fazia sentir. Em 1640, após o fracasso do ataque de Nassau à Bahia, o pastor Soler comentava em cartas aos seus correspondentes: "Os soldados morrem de fome apesar de parte de seus salários ter sido retida para alimentá-los"11 (p.581).

Previsivelmente, os colonos lusos da área rural sofreram as incursões predatórias de soldados esfomeados. Como se desprende do texto das Atas da Assembléia legislativa, as autoridades administrativas da colônia reconheciam:

Há ainda outra espécie de ladrões também mui incommodos e prejudiciaes a respeito dos quaes se faz necessário providenciar pelo damno que causam aos 
moradores, são os soldados indisciplinados que ora surgem nos caminhos, ora vão as casas, e, a pretexto de pedir comida, tomam tudo, maltratam e fazem grandes vexames aos moradores, o que é inteiramente contra a nossa vontade e vós sabeis que querendo remediar este mal temos usado de todo rigor contra os officiaes $^{12}$.

Em Recife, a situação dos colonos não era melhor. Segundo afirmava o pastor Soler:

Agora temos homens (os navios que os trouxeram não pertencem à Companhia) em número suficiente para nos defender, mas não temos víveres. Há cinco ou seis meses que seus preços dobraram. Apenas vegetamos. É a maior miséria que observei nesse país ${ }^{11}$ (p.575).

A notícia da restauração de um monarca luso no trono português, em 1640, colocou um freio às ambições holandesas de assegurar ao Brasil holandês fronteiras mais amplas e defensáveis e um acesso aos portos africanos dedicados ao tráfico negreiro. Valendo-se do intervalo de tempo decorrido entre o anúncio da ruptura entre portugueses e espanhóis e a assinatura oficial de um tratado de paz, Nassau se apressou em tomar de assalto Sergipe, o Maranhão, São Paulo de Loanda e a ilha de São Tomé. Circunstância que enfureceu a população lusa, e deixou à míngua os armazéns da Companhia, desencadeando uma nova crise de abastecimento em 1642 e 1643, que agravou a situação de endividamento da maioria dos senhores de engenho. Nieuhof ${ }^{13}$ atribuiu ao esgotamento dos celeiros da Companhia em meados de 1643, a decisão impopular do Grande Conselho de lançar mão das importâncias devidas à Companhia para poder pagar o salário dos militares e funcionários.

Nassau permaneceu no comando da colônia até meados de 1644. O triunvirato de conseIheiros que o substituiu preocupou-se particularmente com a cobrança das dívidas dos senhores de engenho junto a credores particulares ou à Companhia (dívidas que embutiam juros exor- bitantes). Na área rural, os ânimos lusos acirraram-se de forma explosiva e ao cabo de um ano de relações tensas, os colonos se rebelaram, iniciando uma guerra de libertação que durou nove anos, graças ao auxílio sorrateiro de reforços vindos da Bahia. Nesse período, ambos os adversários experimentaram fome e miséria extremas e, em diversas ocasiões, ambos quase se renderam.

Ao perderem paulatinamente o domínio da área rural, os holandeses foram também perdendo aos poucos o acesso aos mantimentos da terra, a despeito dos provimentos em farinha e em carne bovina do Rio Grande, que continuaram por muitos anos. A dependência do abastecimento europeu voltou a ser crucial. A maioria da população fiel à WIC ficou sitiada na área urbana do Recife e da llha Maurícia, lugares onde somente existiam fontes de água salobra e onde havia pouca madeira para cozinhar. A situação se tornou crítica e gêneros comestíveis pertencentes a comerciantes e a particulares foram confiscados. Praticou-se um racionamento severo dos víveres. Certa vez, uma cesta apetitosa de frutas sumarentas chegou a ser introduzida na cidade, mas as frutas continham veneno. Foi necessário impedir as deserções. Mercenários suspeitos de nutrir intenções de fuga foram enforcados. Aterrorizaram-se os escravos afirmando-lhes que, caso se refugiassem entre os inimigos, seriam comidos pelos índios. Em razão da penúria do abastecimento, as atividades da pesca decuplicaram de importância. Em alguns textos que relatavam os sofrimentos padecidos, como o Diário ou breve discurso acerca da rebelião e dos pérfidos desígnios dos portugueses do Brasi, a alcunha desdenhosa de João Toucinho passou a designar a população colonial lusa ${ }^{14}$.

\section{À mesa dos poderosos não faltaram frutas, hortaliças e carnes saborosas}

O consumo prazeroso de vegetais e animais encontrados no Brasil limitou-se, efetivamente, ao momento áureo e fugaz da prosperidade nassoviana, período de convívio entre forasteiros, 
colonos lusos, indígenas, africanos escravizados, mulatos e mamelucos. A observação dos gêneros comestíveis locais e de suas técnicas de produção, de preparo e de consumo, procedimentos imitados ou alterados, deu início a um recenseamento dos recursos alimentares e à atribuição de valores simbólicos aos novos ingredientes da dieta.

Para os donos do Brasil, o conhecimento da terra prometia a ampliação do rol dos produtos comercializados e um aprimoramento da qualidade de vida cotidiana. Pela força das circunstâncias, a descoberta batava do meio ambiente e dos usos e costumes lusos, repercutiu tanto no imaginário quanto na organização prática de um estilo de vida colonial. Não surpreende, por conseguinte, que os relatórios dos administradores coloniais, fontes documentais destinadas às instâncias metropolitanas da Companhia, e as narrativas de letrados seduzidos pela aventura da WIC tenham registrado de modo consistente o teor das discussões marcantes que ocorriam na capital do Brasil holandês.

Piso, Marcgrave, Zacarias Wagener e João Nieuhof, por exemplo, descreveram algumas das iguarias que incorporavam ingredientes locais. Todavia, a despeito de o médico Piso e de seu assistente, o naturalista Marcgrave, especificarem as denominações indígenas dos alimentos e sua origem nativa, os textos holandeses assinalavam sobretudo os hábitos alimentares dos colonos portugueses. Receitas autóctones, modificadas ao gosto luso pela adição de açúcar, de azeite ou de manteiga, de ovos, de farinha de arroz, de flor de laranjeira (como os beijus ou as marmeladas de mandioca) ${ }^{15}$ foram provadas, elogiadas e adotadas sem grandes questionamentos ${ }^{16}$. Quanto aos animais e aos vegetais provenientes da Europa, da África ou da Ásia, introduzidos na terra pelos colonos lusos, eles foram inventariados pelos cronistas em termos de igualdade com os recursos ameríndios da fauna e da flora.

O conde de Nassau, chefe militar reputado, humanista versado nas artes e nas ciências de seu tempo e nobre formado em diversas cortes europeias, não deixou ao acaso o registro de seus feitos brasileiros. Em uma colônia organizada em torno do açúcar os gêneros comestíveis locais adquiriram valores emblemáticos. As representações dos pintores e dos cientistas convidados a acompanhar Nassau ao Brasil geraram imagens convincentes do domínio holandês. Como destacou José Hygino Duarte Pereira, uma das primeiras providências de governo do conde foi a concepção de brasões para representar o domínio político da WIC. Além do brasão da Câmara de Recife, que ostentava uma donzela segurando um espelho e canas de açúcar, havia tainhas no brasão das Alagoas, caranguejos naquele de Igarassu, cachos de uva representaram Itamaracá e pães de açúcar, a Paraíba ${ }^{8}$.

Merece reparo também o fato de 12 grandes naturezas mortas, cuja autoria foi atribuída ao pintor retratista Albert Eckhout, figurarem as principais espécies vegetais do Novo Mundo, ao lado de vegetais europeus de uso cotidiano como os repolhos ou os nabos. Atrai a atenção, nesses quadros, a existência de correspondências entre detalhes representados e comentários de Marcgrave sobre as maneiras adequadas de cortar a polpa dos ananases ou partir frutos de maracujá15. A ausência em tais composições dos animais nativos apreciados por suas carnes precisa ainda ser ressaltada. Em nenhuma das naturezas mortas brasileiras o artista inseriu peixes, aves ou animais silvestres, procedimento frequente em semelhantes representações. Evitaram-se as imagens de caçadas predatórias. Às frutas, às hortaliças e aos legumes do Brasil coube o papel, provavelmente alegórico, de descrever a fartura local.

Da mesma forma, as célebres representações de tipos humanos brasileiros, compostas por Eckhout e copiadas por Wagener, omitiram diplomaticamente o registro pictórico dos súditos lusos da Companhia. A premissa do domínio holandês, com efeito, residia na exequibilidade da substituição do domínio luso-espanhol por um domínio próprio, tornando necessário minimizar causas de conflitos. Exceto pela constatação que os índios bebiam vinhos de frutas fermentadas e cozinhavam sem acrescentar sal ou óleo às suas 
iguarias, que os portugueses se deliciavam com banha de porco, toucinho ou azeite, preferindo pães doces de farinha branca aos brotes e à manteiga holandeses, as peculiaridades dos antigos e dos novos colonos foram pouco contrastadas simbolicamente por meio de hábitos alimentares.

Se os usos locais portugueses orientaram prioritariamente a seleção dos ingredientes saboreados no Brasil holandês, isso se deveu, provavelmente, ao fato de lusos e holandeses respeitarem ambos os preceitos da medicina humoral (hipocrática ou galênica) vigentes na Europa até meados do século XVIII ${ }^{17}$. Acreditava-se, então, que as doenças resultavam de um desequilíbrio perigoso dos fluidos corporais (os humores) e a saúde, de um estado de equilíbrio do sangue, da bílis amarela ou da bílis negra e da fleuma. Recomendava-se evitar todos os excessos de calor e de secura, que espessariam os humores e os tornariam viscosos, bem como a ingestão de alimentos muito frios e úmidos, que provocariam sua excessiva fluidez.

A relevância dos manejos culinários residia, por conseguinte, em seu papel de auxílio prévio à digestão, considerada um processo interno de cocção. A lógica dos preparos culinários consistia em servir iguarias temperadas. Sal, pimenta e azeite adicionavam-se às carnes nutritivas, vistas como demasiadamente duras e frias. A natureza quente ou fria dos ingredientes comestíveis, ou a melhor maneira de consumi-los eram temas discutidos até pelos mercenários mal pagos e maltrapilhos da Cia da WIC, quando apregoavam as virtudes da garapa azeda, isto é o decantado caldo fermentado das canas.

Outrossim, os comentários suscitados pelos novos ingredientes da dieta evidenciavam a atuação subjacente de um elenco de conceitos que davam forma às práticas sociais. Além da facilidade da digestão, semelhanças de gosto com ingredientes europeus conhecidos, avaliações favoráveis de sabor e considerações de vantagens econômicas presidiram a classificação dos alimentos. Os textos enfatizaram também circunstâncias surpreendentes que destoavam dos usos europeus, como os empecilhos à produção de laticínios ou, como bem enfatizou Nieuhof, a rápida deterioração das carnes que incluía até mesmo aquelas cozidas com adição de vinagre ${ }^{13}$.

O apego dos imigrantes aos hábitos natais não impediu a substituição do pão de trigo pela farinha de mandioca (bem o constatou Moreau) ${ }^{18}$, porém, as iguarias elaboradas com os alimentos nativos não deviam diferir muito das receitas europeias, pois, apenas as especificidades exóticas, como as peculiaridades das carnes de iguanas ou de capivaras, mereceram comentários. O interesse da WIC pelos costumes lusos, entretanto, se revelava inegável. Em o Breve discurso sobre o Estado das quatro capitanias conquistadas se ressaltava, por exemplo, que, não obstante apreciarem comer em baixelas de prata, os portugueses mantinham hábitos frugais. Em suas casas não existiam quadros nas paredes, nem móveis que não fossem estritamente indispensáveis à cozinha, à cama e à mesa:

Não há profusão nos seus alimentos, pois podem sustentar-se muito bem com um pouco de farinha e um peixinho seco, conquanto tenham galinhas, perus, porcos, carneiros e outros animais, de que também usam de mistura com aqueles mantimentos, sobretudo quando comem em casa de algum amigo ${ }^{9}$ (p.66).

Nos engenhos da área rural, o passadio era farto. A honra dos colonos dependia de ostentar hospitalidade generosa. Não faltavam escravos provedores, nem carnes, peixes, crustáceos ou mariscos. Havia também legumes, hortaliças e frutas em abundância. Mas semelhantes confortos se faziam mais raros em regiões de lavouras de mantimentos. Nas Alagoas, segundo um Relatório sobre o estado das Alagoas em outubro de 1643, redigido por Joan van Walbeeck e por Henrique de Moucheron, os cultivadores holandeses que bebiam vinhos em companhia de seus amigos, acabaram falindo ${ }^{19}$.

As refeições holandesas, pois, fundamentaram-se, como as lusas, em um consumo de farinha de mandioca complementado por 
preparos de carnes bovinas secas, salgadas ou frescas e de carnes de caça ou de criações domésticas, acompanhadas de vegetais. Ressaltavam-se nos textos a estima pelos mingaus de carimã com caldos apimentados de carne ou de peixe, pelas carnes bovinas e suínas e pelos peixes. Entre os temperos, citavam-se, além de pimentas nativas com sal (iuquitaia), vegetais notáveis, como o nhambi e o urucum. O comissário Nieuhof assinalava a relevância extrema da pecuária e da pes$\mathrm{ca}^{15}$.

Os escravos africanos conhecedores das técnicas indígenas proviam pescados e mariscos. À diferença da colônia em mãos portuguesas, feiras públicas foram organizadas no Brasil holandês. Pescava-se no litoral com armadilhas, linhas ou redes, pescava-se em alto mar com barcos e com jangadas ao longo dos rochedos da costa. Pescava-se também nos rios, nas lagoas e nos pântanos. Em certos períodos do ano, quando as águas dos rios baixavam, praticava-se a pesca com timbó. Muitos pescadores visavam ao consumo, mas, às vezes, soldados procuravam complementar os salários vendendo os produtos de sua caça ou de sua pesca. Os grandes proprietários adquiriam barris de peixes salgados ou secos fornecidos pelos donos de pesqueiros particulares. Porém, a Companhia das Índias também mantinha seus próprios pesqueiros e importava bacalhaus. Moreau explicava:

No dia da volta de Claesz chegou, também outro navio da Terra Nova, carregado de bacalhau, peixe muito seco, que se assa sobre brasas e come-se com azeite ${ }^{18}$ (p.51).

Havia, entretanto, critérios consistentes permeando as apreciações dos naturalistas e dos curiosos. A preferência ia para os peixes de sabor delicado, cor clara, de carnes abundantes e friáveis com poucas espinhas e uma gordura natural que dispensava regá-los com azeite. Tais peixes eram assados. Evitavam-se cozinhar em água aqueles que continham muitas espinhas. Gabava-se o gosto adocicado de peixes apanhados junto aos rochedos. Outros, cujas carnes eram magras, serviam- -se fritos ou grelhados com azeite, limão e pimentas nativas. Outros ainda preparavam-se em escabeche com azeite e vinagre.

Nas hortas e nos pomares também havia fartura. Legumes variados acompanhavam os mantimentos básicos. Parece que costumavam ser preferencialmente cozidos em água e servidos com azeite ou manteiga e pimenta. Receitas europeias de espinafres e de acelgas serviram de modelo para o preparo de receitas de vegetais locais, como o perrexil do mar e as folhas de taioba ${ }^{15}$, todavia, segundo notavam Nieuhof e Marcgrave, frutas como os mamões acompanhavam também as carnes e os peixes ${ }^{15}$. No Breve discurso, Nassau enumerava:

Têm belíssimas frutas, como laranjas, limões, melões, melancias, abóboras, pacovas, bananas, ananazes, batatas, maracujá-açu, maracujá-mirim, araticum-apê e o belo e o mais delicioso dos frutos, a mangaba, e ainda vários legumes, milho, arroz e outros mais, de que fazem diversidade de confeitados. Estes são muito sãos, e deles comem em quantidade $^{9}$ (p.109).

Considerava-se perigosa a ingestão de frutas cruas e frias, mas, segundo Piso, era benéfico comê-las tomando-se precauções. Laranjas, por exemplo, quando comidas no desjejum ou no início das refeições, faziam bem à saúde ${ }^{9}$. O sabor da maioria das frutas brasileiras deslumbrou os holandeses. Muitos autores descreveram mangabas e ananases em termos entusiastas. Apresentando as melancias, Wagener afirmava:" chamadas pelos nossos de limão d'água [...] têm sabor suave e agradável, estando repletas de suco adocicado e são muito saudáveis [...] refrescam e aliviam o organismo cansado e enfraquecido" 20 .

Por seu gosto explícito pelas frutas brasileiras, o conde de Nassau deu o exemplo. Fez questão de possuir nos jardins de seu palácio exemplares de todas as variedades interessantes que o Brasil produzia. Mas, exceto no que dizia respeito aos amendoins, sobremesa indígena, considerada afrodisíaca, e às conservas em calda 
de açúcar que as mulheres dos colonos lusos sabiam preparar, poucas informações explícitas sobre receitas foram registradas pelos autores. Abóboras, mangabas, araçás, ananases, cajus, frutos de cabaças, pimentões, gengibre, talos de alfaces etc., confeitados, foram degustados, já que, apesar de o açúcar constituir um produto, sobretudo destinado à exportação, a transformação das frutas em doces permitia evitar as doenças de natureza fria.

Do mesmo modo que sob domínio português, o cotidiano holandês proporcionou dietas diferentes às camadas pobres e ricas da sociedade. Tubérculos substanciais, como as batatas doces que provocavam flatulências, costumavam ser adquiridos pelas pessoas mais pobres. Existiu também um consumo diferenciado das bebidas não alcoólicas. À garapa doce dos menos remediados contrapunham-se os xaropes de açúcar clarificado das elites ${ }^{21}$.

Coube também um papel diacrítico evidente aos peixes, cujo consumo assinalou a posição social dos comensais. Peixes valorizados, adquiridos pelos magnatas alcançavam preços elevados. Enquanto os privilegiados saboreavam ovas de robalo prensadas e secas (as botargas, preparo difundido na Europa e no Oriente Médio), apreciando música e bebendo cerveja nos jardins da Cidade Maurícia, soldados aquartelados em Recife consumiam garapa nas tavernas da rua do vinho e comiam, como os escravos, peixes de poucas carnes ou de textura visguenta. Os bagres, todavia, peixes sem escamas, que os judeus não compravam, tinham sabor agradável e preço moderado.

Além do apetite dos holandeses pelas bebidas alcoólicas, prevalecia seu gosto pelos líquidos adoçados, por refrescos com limões ou por infusões de erva cidreira. O Breve discurso reparava: "a bebida dos portugueses é principalmente água da fonte que é muito boa e agradável; nela ensopam um pedaço de pão de açúcar e vão chupando o que é muito são e refrescante" 9 (p.109).

E Nieuhof registrava: "Os portugueses e holandeses preparam um refresco com água, açúcar, e limão. Ás vezes, põem de infusão certas ervas, outras vezes usam apenas água com limão"13 (p.381).

Em ambiente palaciano não faltavam o pão, os peixes servidos com manteiga e mostarda, os queijos holandeses, as goiabas com ervas cozidas em vinho e as marmeladas de mandioca, uma abundância que não se verificava em todos os lares e quartéis da colônia. Todavia, mesmo que em certas ocasiões a população estivesse reduzida a comer aves com sabor pronunciado de maresia, insetos, como as formigas, e outros alimentos estranhos, a descoberta holandesa da terra brasileira, efetuada por meio do paladar, parece ter oferecido compensações tão prazerosas aos cronistas que, ricos ou pobres, eles fizeram questão de relatar as minúcias do cotidiano colonial.

\section{CONSIDERAÇÕ ES FINAIS}

Um exame circunstanciado dos problemas alimentares que afligiram o Brasil holandês revelou a fragilidade do domínio político conquistado pela WIC. Reservas insuficientes de víveres e de mantimentos locais impediram a independência da colônia em relação ao envio de alimentos europeus, o que dificultou a ampliação da conquista e a aceitação da nova sujeição por parte dos colonos portugueses que produziam açúcar e gêneros alimentícios.

A descrição dos hábitos alimentares e dos problemas de abastecimento encontrados na documentação analisada permitiu apontar os parâmetros sócio-culturais que regiam aquela sociedade, favorecendo um enfoque bem documentado sobre a alimentação da época.

\section{REFERÊ NCIAS}

1. Pudsey C. As memórias de Cuthbert Pudsey sobre o Brasil holandês (1629-1640). História Naturalis. Seropédica. 2000; 3:1-262.

2. Salvador FV. História do Brasil 1500-1627. $5^{\text {a }}$ ed. São Paulo: Melhoramentos; sem data. p.451. 
3. Coelho DA. Memórias diárias da guerra do Brasil. Recife: Secretaria do Interior de Pernambuco; 1944. p.113.

4. Mello EC. Olinda restaurada: guerra e açúcar no nordeste (1630-1654). $2^{a}$ ed. Rio de Janeiro: Topbooks; 1998. p.63.

5. Laet J. História ou anais dos feitos da Companhia Privilegiada das Índias Ocidentais. Rio de Janeiro: Biblioteca Nacional; 1916. p.522-23.

6. Neto JAGM. Tempo dos flamengos. Rio de Janeiro: José Olympio; 1947. p.44.

7. Papavero CG. Mantimentos e víveres: o domínio colonial holandês no Brasil [dissertação]. São Paulo: Universidade de São Paulo; 2002.

8. Pereira JHD. Batalha naval de 1640 e outras peripécias da guerra holandesa no Brasil. RIHGB. 1895; 58(91):1-58

9. Breve discurso sobre o estado das quatro capitanias conquistadas de Pernambuco, Itamaracá, Paraíba e Rio Grande, situadas na parte setentrional do Brasil. In: Mello JAGM, organizador. Fontes para a história do Brasil holandês. Recife: MEC; 1981. p.1-109.

10.Zacharias TW. In Teixeira D, organizador. Brasil holandês: documentos da biblioteca universitária de Leiden. Rio de Janeiro: Index; 1997. p.116-7.

11. Bots H., Leroy PE. Le Brésil sous la colonisation néerlandaise. Douze lettres de Vincent- Joachim Soler, pasteur à Recife, à André Rivet (1636-1643). Bulletin de la Société de l'Histoire du Protestantisme Français. 1984; 130(4):556-94.
12. A primeira assembléia legislativa no Brasil. RIHGB. 1893; 56(87):117-39.

13. Nieuhof J. Memorável viagem marítima e terrestre ao Brasil. São Paulo: EDUSP; 1989 p.72-328.

14. Diário ou breve discurso acerca da rebelião e dos pérfidos desígnios dos portugueses do Brasil, descobertos em junho de 1645 e do mais que se passou até 28 de abril de 1647. RIAGP. 1887; 4(32): 121-225.

15. MarcGrave J. História natural do Brasil. São Paulo: Museu Paulista; 1942. p.33-70

16. Piso G. História natural do Brasil. São Paulo: Ed. Nacional; 1948. p.58-62.

17. Hippocrate. L'art de la médecine. Paris: Flammarion; 1999.

18. Moreau P. História das últimas lutas no Brasil entre holandeses e portugueses. São Paulo: EDUSP; 1979. p.46-62.

19. Walbeeck JV, Moucheron H. Relatório sobre o estado das Alagoas em outubro de 1643. RIAGP. 1886; 4(35):153-65.

20. Wagener Z. O "Thierbuch". In: Teixeira D, organizador. Brasil holandês: documentos da biblioteca universitária de Leiden. Rio de Janeiro: Index; 1997. p.98-9.

21. Antonil AJ. Cultura e opulência do Brasil. $2^{\text {a }}$ ed. São Paulo: Nacional; 1967. p.203.

Recebido em: 3/9/2009 Aprovado em: 2/2/2010 
